\title{
PUBLISHER CORRECTION OPEN \\ Publisher Correction: Development and validation of a deep learning algorithm for improving Gleason scoring of prostate cancer
}

Kunal Nagpal, Davis Foote, Yun Liu, Po-Hsuan Cameron Chen, Ellery Wulczyn, Fraser Tan, Niels Olson, Jenny L. Smith, Arash Mohtashamian, James H. Wren, Greg S. Corrado, Robert MacDonald, Lily H. Peng, Mahul B. Amin, Andrew J. Evans, Ankur R. Sangoi, Craig H. Mermel ID, Jason D. Hipp and Martin C. Stumpe

npj Digital Medicine (2019)2:113; https://doi.org/10.1038/s41746-019-0196-8

Correction to: npj Digital Medicine https://doi.org/10.1038/ s41746-019-0112-2, published online 7 June 2019

The original version of the published Article omitted an affiliation for the last Author, Martin C. Stumpe. The last Author's affiliation has been updated to include Google Al Healthcare, Google, Mountain View, CA, USA. This has been corrected in the $\mathrm{HTML}$ and PDF version of the Article.

\begin{abstract}
cc (i) Open Access This article is licensed under a Creative Commons Attribution 4.0 International License, which permits use, sharing, adaptation, distribution and reproduction in any medium or format, as long as you give appropriate credit to the original author(s) and the source, provide a link to the Creative Commons license, and indicate if changes were made. The images or other third party material in this article are included in the article's Creative Commons license, unless indicated otherwise in a credit line to the material. If material is not included in the article's Creative Commons license and your intended use is not permitted by statutory regulation or exceeds the permitted use, you will need to obtain permission directly from the copyright holder. To view a copy of this license, visit http://creativecommons. org/licenses/by/4.0/.
\end{abstract}

(c) The Author(s) 2019 